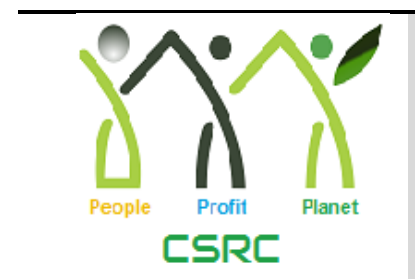

Volume and Issues Obtainable at Center for Sustainability Research and Consultancy

Journal of Accounting and Finance in Emerging Economies ISSN: 2518-0318 ISSN (E) 2518-8488

Volume 6: Issue 2, June 2020

Journal homepage: www.publishing.globalcsrc.org/jbsee

\title{
Nexus between Volatility of Stocks and Macroeconomic Factors during Global Financial Crisis: Evidence from Conventional \& Islamic Stocks
}

\begin{abstract}
${ }^{1}$ Majid Imdad Khan, ${ }^{2}$ Waheed Akhter, ${ }^{3}$ Muhammad Usman Bhutta
${ }^{1}$ Ph.D Scholar, Deptt. Management Sciences, COMSATS University Islamabad, Lahore Campus, Pakistan, scc.ranamajid@ gmail.com

${ }^{2}$ Assistant Professor, Center of Islamic Finance, COMSATS University Islamabad, Lahore Campus, Pakistan, drwaheed@cuilahore.edu.pk

${ }^{3}$ Assistant Professor, Deptt. Management Sciences, COMSATS University Islamabad, Lahore Campus, Pakistan, usman.bhutta@cuilahore.edu.pk

\begin{tabular}{l}
\hline \multicolumn{1}{c}{ ARTICLE DETAILS } \\
\hline History \\
Revised format: May 2020 \\
Available Online: Jun 2020 \\
Keywords \\
Shanghai Stock Exchange, \\
Interbank Offer Rate, Dow \\
Jones World Islamic Index, \\
Consumer Price Index, Oil \\
Price \\
\hline
\end{tabular}

JEL Classification

H83, M41

\section{ABSTRACT}

Purpose: The study explores the relationship between the volatility of stock return of markets (Islamic \& conventional) and macroeconomic factors by using GARCH in Mean $(1,1)$ model during global financial crisis.

Design/Methodology/Approach: monthly data for the period from 04 Jan, 2005 to $31^{\text {st }}$ Dec, 2015. The Islamic stock markets (Dow Jones Islamic Market Malaysia (DJIM), Dow Jones Islamic Market Indonesia (DJII) \& Dow Jones world Islamic Index (DJWI)-Benchmark), Conventional stock markets (Shanghai Stock Exchange (SSE),Bombay Stock Exchange (BSE) \& Pakistan Stock Exchange (PSE) and Macroeconomic factors (Inflation, Interest Rate, Oil prices and Industrial Production) are taken into consideration.

Findings: The results explored that inflation rate influenced the returns of conventional stock markets than Islamic stock markets. Moreover, the volatility components for macroeconomic factors i.e. inflation, interest rate and oil prices are more volatile but larger to industrial production during global financial crisis.

Implications/Originality/Value: However, the frequency of market volatility for Islamic stock market is lower than conventional stock markets that mean that the investment in Islamic stock markets seems to be safe flight than conventional stock markets during global financial crisis.
\end{abstract}

(C) 2020 The authors, under a Creative Commons AttributionNonCommercial 4.0

Corresponding author's email address: scc.ranamajid@gmail.com

Recommended citation: Khan, M. I., \& Akhtar, W., \& Bhutta, U.M., (2020). Nexus between Volatility of Stock and Macroeconomic Factors: Evidence from Conventional \& Islamic Stocks. Journal of Accounting and Finance in Emerging Economies, 6 (2), 465-47. https://doi.org/10.26710/jafee.v6i2.1197 


\section{Introduction}

Islamic finance industry plays an important role to signify the diversification of portfolio as compare to conventional one. The predictability of future stock returns exists (Fama, 1970) but the debate is still controversial (Ang and Bekaert, 2006). The studies in different periods have much evidence about stock returns but a question mark (Fama and French, 1988; Campbell \& Yogo, 2006; Hammoudeh et al., 2014; Balcilar, Demirer, and Hammoudeh, 2015; Aloui et al., 2015; Saiti and Masih, 2016; Bahloul et al., 2017 ;Goles \& Koudijs, 2018 and Liu et. all., 2019). The market related activities are not dependent to Islamic principles (Zain, Darus, and Ramli, 2015) but supposed to be a risk-return trade mark with conventional stocks (Reddy et al., 2017; Al-Awadhi and Dempsey, 2017). The Islamic finance has attracted the researchers globally since 1980s. The debt crisis and shocks ear have also created the interest of researcher when the shocks absorbed into a full ledge system of banks in the era of 1990s. The Sharia compliant finance industry introduced the concept of Islamic finance, which is different from conventional finance. The volatile behavior in stock returns always remained a question mark for the investors who observed risk to take the investment decision. Higher the volatility may arise higher level of risk in stock returns and other factors of the market. Volatility is expressed statistically as dispersion in returns of security or financial market index. The security is said to be riskier than other if has higher level of volatility. The behavior of investors become risk averse in a case of excessive volatility which lose confidence of investors. The development of an economy could be enhanced to accelerate the performance of stock market. The mobility of capital domestically or internationally is essential for a well-structured stock market while restrict the economic development being inefficient capital flow of market (Fernando, 2018). The volatility increases the risk in stock market, explored instability or crises for an economy (Demir, 2019). The transactions which have greater magnitude exposed to larger volatility.

The changes in macroeconomic factors accelerate the effect of stock returns volatility (Haider, Haider \& Ahmed, 2017). The recent studies are evident that there is relationship between volatility of stock returns and macroeconomic factors (Mala and Reddy, 2007; Onakoya, 2013; Emenike \& Okwuchukwu, 2014; Jareno and Negrut, 2016; Hasan and Zaman, 2017; Fernando, 2018; Baker et. all., 2019; Demirer et. all., 2019 and Hamad, Peretti, \& Charfi, 2019). The impact of information asymmetry on return of stock market, forecast of stock market returns, macroeconomic factors in the market and their volatilities play an important role in economy, specifically in relation to efficient market hypothesis (EMH). The fraction or volatility in stock returns \& macroeconomic factors are the focus of study. In 1970s era, relationship between stock returns of USA and inflation explored by different researchers and found negative relation (Bodie, 1976; Fama and Schwert, 1981; Pearce and Roley, 1983 \& 1985 and Chen et all., 1986). The spread in term structure in the USA stock market found as the difference between interest rate in short run as well as long run (Chen et. all., 1986). The high \& low spread in bonds are contributed risk factors for USA stock market, expectedly and unexpectedly observed in relation to spread in inflation, industrial production by using Arbitrage Pricing Theory (Chen et. all., 1986). The study explored the high volatilities in bust phases.

The key focus of study is to determine the volatility in stock returns of Islamic stock market and conventional stock market in relation to macroeconomic factors during global financial crisis. In particular, we will focus on the impact of macroeconomic factors in context of volatilities either the Islamic stock markets are more macro driven or conventional stock markets? 
The remaining part of this paper is to be presented as follows. Section 2 Section-3 describes the data \& econometric models to explore the volatile impact of macroeconomic factors on stock returns. Section-4 will explore the results \& discussion on findings. Finally, Section-5 will conclude the results.

\section{Literature Review}

Macroeconomic factors play a vital role in explaining the comovement and volatility in stock market returns. Macroeconomic indicators fluctuate the firm's value, cash flow as well as risk adjusted discounting rate (Flannery \& Protopapadakis, 2002). The relationship of macroeconomic factors with stock market returns have been first proposed by Sharp \& Lintner through Black SLB (CAPM) model. This model covers one factor significantly. The sense of Markowitz (1959) have interesting role, particularly explores the relationship between stock returns and the stock market positively. This approach further supported by Black, Jenson \& Scholes (1972) as well as MacBeth (1973).

As for as later, the CAPM-model didn't prove supportive (Fama and French, 1989). He pointed out that there are limitations for the model. Time to time assumptions were added and introduced multifactor approach after efforts of different researchers (Bilson et. all., 2001; Chen et. all., 1986; Cheung et. all., 1998; Fama, 1981; Fama, 1990; Ross; 1976; Rapach, Wohar \& Rangvid, 2005). These were the studies through which the relationship between stock price and macroeconomic factors have been explored. Different researchers have worked on different macroeconomic factors to explore the relation with stock price. The cointegrated relation between inflation, interest rate, money supply \& exchange rate \& stock price has been explored (Maysami \& Koh, 2000). APT theory tested in Malaysia \& other regions of the world for the purpose to explore the relation between macroeconomic factors and stock prices (Khoon \& Gupta, 2001; Al-Sharkas, 2004; Agyire \&Tettey, 2008; Hsing and Hsieh, 2012). The oil industry is very much important because it generate electricity \& energy, transport run, use to convert the products to final consumer (Nizar, 2012). Moreover, the oil lays a vital role in the way to explore the shocks transmission in price of goods as well as price of stock markets during global financial crisis (Roubaud \& Arouri, 2018).

The previous studies are evident in which estimate time varying transmission regarding volatility and movement of stock returns volatility during global financial crisis; Asia in 1997-1998, Russia in 1998, Brazil in 1999, 2007-2008 \& US in 2000 (Duncan and Kabundi, 2013 and 2014). Bad news has larger effect on volatility as compare to good news for stock markets of DJUSI and DJEMI during the period of global financial crisis (El-Mehdi and Mghaieth, 2017).

In light of above discussion, it is observed that a very limited work has been done to explore the volatility with the use of macroeconomic factors (El, Koury, 2015 and Kruger \& Rhein, 2015). The most of the studies considering macroeconomic factors as explanatory variables to explore the relationship between stock returns. But this study will eliminate the relationship of stock returns and macroeconomic factors by using the GARCH in Mean $(1,1)$ model \& in context of Islamic stock. Thus, the literature suggests that there may be linkages between stock market volatility and macroeconomic factors for the different countries. This study is an effort to revisit the relationship of stock markets i.e. Islamic stock markets and conventional stock markets with macroeconomic factors. The purpose is to explore that either the Islamic stock markets are macro driven or conventional stock markets. Moreover, the variables are associated with monetary policy as well as fiscal policy; which would be favorable upon results or expected affect the frequency of the volatility in stock markets.

\section{Methodology}

The investigation of volatility in return series of Islamic stock market and conventional stock market i.e. Malaysia, Indonesia and Dow Jones World Islamic Index (Benchmark) and China, India and Pakistan are taken into consideration respectively. The monthly data was used and collected from yahoo finance \& Data Stream websites. The macroeconomic data was collected during global financial crisis from 
world bank website. The period of data is Jan 04, 2005 to Dec $31^{\text {st }}, 2015$. The return of Islamic and conventional stock markets is to be calculated as follows.

$$
r_{t}=\ln \left(\frac{\mathrm{P}_{t}}{\mathrm{P}_{t-1}}\right)
$$

Where $r_{t}$ represent return of market for stock price index, $\ln$ as natural $\log , \mathrm{P}_{t}$ denoted as present price at time $\mathrm{t}$ and $\mathrm{P}_{t-1}$ represents as stock price at previous time.

\subsection{Returns and Volatility}

The volatility could be measured through non-linear model regarding objective of study. The GARCH in Mean $(1,1)$ model permits for conditional means and variance. The risk through volatility can be measured in conditional variance by the way to enter into conditional mean. The key objective of study is attained to examine the nexus between volatility of stock and macroeconomic variables as bellows.

\subsection{Returns, Volatility and Macroeconomic Factors}

The monthly data was used for macroeconomic factors (Interbank offer rate, proxy of interest rate, inflation rate, oil prices, and industrial production). The data was collected from world bank website. The volatility is to be modeled regarding macroeconomic factors as under.

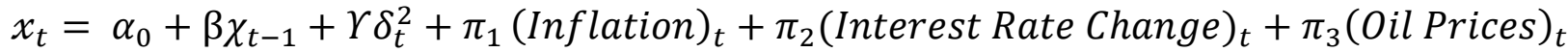

$$
\begin{aligned}
& \left.+\pi_{4} \text { (Industrial production }\right)_{t} \\
& +\varepsilon_{t}
\end{aligned}
$$

Where $x_{t}$ is return at time $\mathrm{t}, \alpha_{0}$ is constant, $\beta, \mathrm{Y}, \pi$, and $\varepsilon_{t}$ is error term. The macroeconomic factor's coefficient would be statistically significant then influence the market returns.

$$
v_{t}=\gamma_{0}+\sum_{i=1}^{p} v_{t-1}+\sum_{j=1}^{q} \Upsilon_{j} \mu_{t-j}^{2}+\sum_{k=1}^{m} \mu_{k} L_{k}
$$

Where $v_{t}$ is expressed as variance, $L_{k}$ is Macroeconomic variables that define the enhancement of variance.

\subsubsection{Inflation Rate (IR)}

Inflation is measured as consumer price index (CPI). The average changes in goods price \& services for a particular period is taken to compute this variable as under.

$$
\text { Inf Rate }=\mathrm{I}_{r t}=\operatorname{Ln}\left(C P I_{t} / C P \mathrm{I}_{t-1}\right)
$$

Where $\mathrm{I}_{r t}$ is denoted for inflation rate, $C P \mathrm{I}_{t}$ is representing closing value of $C P \mathrm{I}$ at time $\mathrm{t}$, further, $C P \mathrm{I}_{t-1}$ is used for closing value of $C P \mathrm{I}$ at time $\mathrm{t}$ of previous period.

\subsubsection{Interest Rate Change}

The interbank offer rate is taken as proxy of interest rate and could be measured as follows.

$$
\ln (\text { Interest Rate Change })=\mathrm{I} N_{r t}=\ln \left(\mathrm{I} K_{t} / \mathrm{I} K_{t-1}\right)
$$

Where Interest Rate change $=\mathrm{I} N_{r t}$,

Closing price of Interbank offer rate at time $\mathrm{t}=\mathrm{I} K_{t}$, and Closing price Interbank offer rate at previous time $1=I K_{t-1}$

\subsubsection{Oil Prices}

Brent oil prices are taken as proxy of oil prices. The increase in value indicates increase in cost of production which will reduce earnings as well as profit margins in corporate sector as the demand reduced for a product. The volatility might influence the stock returns which effect oil prices, presented as under.

$$
\text { Log difference }(\text { Oil Prices })=\operatorname{Ln}\left(\text { Ő } P_{r t}\right)=\ln \left(\text { Ő } P_{t} / \text { Ô } P_{t-1}\right)
$$

Where $L n$ denoted as $\log$ difference in oil prices, Ő $P_{t}$ for closing prices of oil at time t, Ő $P_{t-1}$ for closing prices of oil at previous time $t$.

\subsubsection{Industrial Production}

The real sector growth rate taken as proxy of industrial production. The overall activity of economy is represented by industrial production and influence the stock return volatility depend on expected price of future cash flows. The equation is written as under. 
Log difference $($ Index of Industrial Production $)=$ Real Sector Growth Rate $=R S G R_{r t}=$

$$
\operatorname{Ln}\left(\frac{\mathrm{II} P_{t}}{\mathrm{II} P_{t-1}}\right)
$$

Where $R S G R_{r t}$ is denoted as growth rate of real sector i.e. measured as the change in index of industrial production). II $P_{t}$ is representing industrial production index value at time $\mathrm{t}$ and $\mathrm{II} P_{t-1}$ is for industrial production index value for previous time $t$.

4. Results and Discussion

\begin{tabular}{|c|l|c|c|c|c|c|c|}
\hline & & \multicolumn{3}{|c|}{ Conventional Stocks } & \multicolumn{3}{c|}{ Islamic Stocks } \\
\hline Statistics & Parameters & SSE & BSE & PSE & DJIM & JKII & DJWI \\
\hline \multirow{2}{*}{} & $\alpha_{0}$ & -0.28555 & 0.055 & -0.03422 & -1.087542 & 0.063843 & 0.33708 \\
\cline { 2 - 8 }
\end{tabular}

The behavior of return as well as volatility for stock markets (China, India, Pakistan, Malaysia, Indonesia) \& Dow Jones World Islamic index (Benchmark) explored. The data includes monthly stock series for the period from 04 Jan, 2005 to $31^{\text {st }}$ Dec, 2015. The descriptive statistics explored the behavior of data as under.

\section{Table-4.1}

Descriptive Statistics of Daily Returns of Equity Markets; for the period from 04 Jan, 2005 to 31 Dec, 2015.

\begin{tabular}{|l|r|r|r|r|r|r|}
\hline & \multicolumn{2}{|c|}{ CONVENTIONAL STOCKS } & \multicolumn{1}{c|}{ ISLAMIC STOCKS } \\
\hline & \multicolumn{1}{c|}{ SSE } & \multicolumn{1}{c|}{ BSE } & \multicolumn{1}{c|}{ PSE } & \multicolumn{1}{c|}{ DJIM } & \multicolumn{1}{c|}{ JKII } & \multicolumn{1}{c|}{ DJWI } \\
\hline Mean & 0.000279 & 0.000487 & 0.000698 & 0.000292 & 0.000461 & 0.000205 \\
\hline Median & 0.000328 & 0.000917 & 0.011002 & 0.000000 & 0.000710 & 0.000272 \\
\hline Maximum & 0.090343 & 6.907775 & 0.082547 & 0.046339 & 0.357871 & 0.098359 \\
\hline Minimum & -0.092562 & -6.926878 & -0.060418 & -0.109394 & -0.178216 & -0.084247 \\
\hline Std. Dev. & 0.017506 & 0.177394 & 0.012779 & 0.007694 & 0.017601 & 0.010138 \\
\hline Skewness & -0.470907 & -0.181359 & -0.410670 & -1.242298 & 2.251391 & -0.446421 \\
\hline Kurtosis & 7.011116 & 1496.54500 & 6.207488 & 22.210450 & 67.556570 & 14.837640 \\
\hline Jarque-Bera & 2187.0840 & 287000000.00 & 1412.3460 & 48340.170 & 539531.60 & 18156.070 \\
\hline Probability & 0.0000 & 0.0000 & 0.0000 & 0.0000 & 0.0000 & 0.0000 \\
\hline
\end{tabular}

Table 4.1 explores the results of stock markets (Islamic and Conventional) (SSE, BSE, PSE, DJIM, JKII and DJWI). The description of data reveals that there are 06 stock markets i.e. Shanghai Stock Market (SSE-China), Bombay Stock Exchange (BSE-India), Pakistan Stock Exchange (PSE-Pakistan), Dow Jones Stock Market for Malaysia (DJIM), Dow Jones Islamic Stock Market for Indonesia/Jakarta Islamic Index (JKII), and Dow Jones World Islamic Index (Benchmark)-(DJWI). The returns of PSE found higher on average but the SSE \& BSE expressed as riskier markets. The stock markets; SSE, BSE, PSE, DJIM \& DJWI are found negatively skewed but JKII remained positively skewed. The test of Jarque-Bera explored the normality which found non-normal regarding all the series of stock.

Table-4.2

Estimation of GARCH in Mean $(1,1)$ for Returns, Volatility and Macroeconomic Model for SSE, BSE, PSE, DJIM, JKII and DJWI to Determine the Impact of Macroeconomic Factors on Returns during Global Financial Crisis. 


\begin{tabular}{|c|c|c|c|c|c|c|c|}
\hline \multirow{13}{*}{$\begin{array}{c}\text { Mean } \\
\text { Equation }\end{array}$} & p-value & $<0.00001$ & 0.9361 & 0.6669 & 0.0754 & 0.3466 & 0.8653 \\
\hline & $B$ & -0.06193 & 0.029244 & 0.140654 & 0.062869 & 0.078928 & 0.32668 \\
\hline & p-value & $<0.00001$ & 0.3475 & 0.2474 & 0.0161 & 0.6536 & 0.0551 \\
\hline & $\Upsilon$ & 4.478295 & -88.5838 & 5.810543 & 0.096872 & -0.692053 & -51.2892 \\
\hline & $\mathrm{p}$-value & $<0.00001$ & 0.4694 & 0.4985 & 0.4253 & 0.4936 & 0.8843 \\
\hline & $\pi_{1}$ & 0.084942 & -0.02007 & -0.36845 & -1.50639 & 0.400508 & -0.08529 \\
\hline & p-value & $<0.00001$ & 0.9282 & 0.8977 & 0.4366 & 0.8798 & 0.9438 \\
\hline & $\pi_{2}$ & -0.58652 & 0.002364 & -0.30269 & -0.074 & -0.65527 & 0.22398 \\
\hline & p-value & 0.3595 & 0.9827 & 0.0739 & 0.3558 & 0.0008 & 0.8949 \\
\hline & $\pi_{3}$ & 0.004632 & 0.002364 & 0.038964 & 0.0536302 & 0.008208 & 0.04087 \\
\hline & $\mathrm{p}$-value & 0.2274 & 0.9856 & 0.988 & 0.7065 & 0.9807 & 0.9089 \\
\hline & $\pi_{4}$ & -0.06258 & 0.092464 & 0.061548 & 0.077654 & -0.02227 & -0.03332 \\
\hline & $\mathrm{p}$-value & 0.032 & 0.2957 & 0.6849 & $<0.00001$ & 0.9487 & 0.7762 \\
\hline \multirow{6}{*}{$\begin{array}{l}\text { Variance } \\
\text { Equation }\end{array}$} & $r_{0}$ & -0.00039 & 0.000204 & 0.005098 & 0.0000198 & 0.002804 & 0.00475 \\
\hline & $\mathrm{p}$-value & $<0.00001$ & 0.591 & 0.6542 & 0.4965 & 0.2598 & 0.0488 \\
\hline & $\delta$ & 0.0263624 & 0.994127 & 0.607351 & 0.980204 & 0.423533 & 0.09800 \\
\hline & p-value & $<0.00001$ & $<0.00001$ & 0.653 & $<0.00001$ & 0.3626 & 0.8808 \\
\hline & $Y^{1}$ & 0.740924 & -0.006592 & -0.049851 & 0.786177 & 0.435965 & 0.04225 \\
\hline & p-value & $<0.00001$ & 0.4998 & 0.7944 & $<0.00001$ & 0.0056 & 0.8804 \\
\hline \multirow{3}{*}{$\begin{array}{c}\text { Diagnostic } \\
\text { Testing }\end{array}$} & $\begin{array}{c}\text { AIC - } \\
\text { Statistics }\end{array}$ & 40.41289 & -3.75854 & -1.93804 & -6.41929 & -2.285137 & -2.5705 \\
\hline & SIC - Statistics & 40.63354 & -2.986746 & -1.78557 & -6.39933 & -2.285137 & -2.3489 \\
\hline & $\begin{array}{l}\text { Log. } \\
\text { Likelihood }\end{array}$ & -2970.32 & 161.5784 & 143.8995 & 3962.969 & 175.6308 & 180.673 \\
\hline
\end{tabular}

Table 4.2 represents the results of SSE, BSE, PSE, DJIM, JKII \& DJWI, observed through GARCH in Mean $(1,1)$ model which further extended and entered the explanatory variables. The explanatory variables are the macroeconomic factors, taken into equation and found significant for conditional mean at the value $\mathrm{P}<0.10$. The inflation explaining the liquidity effect in short run and have significant relationship with SSE. There found negative relationship between SSE and oil prices that mean with the increase in oil prices the returns of SSE tend to decreasing. The negative relation between inflation and BSE found that mean that with the increase in inflation the returns of stock market BSE tend to decreasing. Negative relation found in between interbank offer rate and PSE. A positive relation was found between oil prices and DJIM. There was positive impact of interbank offer rate with stock market JKII that mean with the increase in interest rate coincide with decreases in returns of JKII. There found no effect of macroeconomic variables on returns of DJIW. Overall results suggested that macroeconomic factors impacting negatively \& positively to returns of all Islamic stock markets except DJWI. The selection of model based on AIC, SIC \& log likelihood criterion. The overall results explored that inflation effect the returns of conventional stock markets but not Islamic stock markets. The change in interbank offer rate (proxy of interest rate) explored negative relation with both the Islamic stock markets as well as conventional stock markets. There was no significant impact of oil prices on markets. The $5.3 \%$ change of oil prices positively found in returns of Malaysian market. The industrial production has significant impact on SSE-China stock market in comparison to DJIMMalaysia stock markets among Islamic and Conventional stock markets. However, the impact found negative in China that means that with the increase in industrial production reducing returns but opposite in stock market of Malaysia. Moreover, the volatility component suggested that macroeconomic factors of inflation, interest rate, oil prices are more volatile but larger to industrial production. However, the frequency of market volatility for Islamic stock market is lower than conventional stock markets. 


\section{Conclusion}

We conclude, in this paper, the results regarding nexuses between volatility of Islamic and Conventional stock market returns and macroeconomic factors. Using GARCH in Mean $(1,1)$ model to explore the volatility and persistency of shocks of the variables and their impacts on variables. Moreover, the results also concluded that the Islamic stock market returns are macro driven or conventional stock markets. The overall results concluded that inflation effect the returns of conventional stock markets but not Islamic stock markets. The change in interbank offer rate (proxy of interest rate) explored negative relation with both the Islamic stock markets as well as conventional stock markets. The industrial production has significant impact on SSE-China stock market in comparison to DJIM-Malaysia stock markets among Islamic and Conventional stock markets. The impact found negative in China that means that with the increase in industrial production reducing returns but opposite in stock market of Malaysia. The volatility component suggested that macroeconomic factors of inflation, interest rate, oil prices are more volatile but larger to industrial production. However, the frequency of market volatility for Islamic stock market is lower than conventional stock markets. Investors may consider Islamic stock markets than conventional stock markets for diversification of portfolios at the time of shocks in stock market of the world. The lower the volatility in times of major shocks suggested to financial authorities who could decide monetary policy when the shocks hit the financial markets. The results are explored robust to consider alternative specifications and the sample may be splitted in analysis. The study is helpful in context of the exposition of portfolio diversification, volatility for returns of stock \& macroeconomic factors during global financial crisis for G-7 countries or other world in future.

\section{References}

Al-Awadhi, M., A and Dempsey, M. (2017), "Social norms and market outcomes: The effects of religious beliefs on stock markets", J. Int. Financ. Markets. Inst. Money, Vol. 50, 119-134.

Alaoui, A., Dewandaru, G., Rosly, S.A., Masih, M., (2015). Linkages and co-movement between international stock market returns: case of Dow Jones Islamic Dubai financial market index. J. Int. Financ. Mark. Inst. Money 36, 53-70.

Ang A, Bekaert G (2006) Stock return predictability: is it there? "Rev Financ Stud", Vol. 20(3), 651707.

Bahloul, S., Maria, M. and Naifar, N. (2017), "The impact of macroeconomic and conventional stock market variables on Islamic index returns under regime switching”, Borsa Istanbul Review, Vol. 17 No. 1, 62-74.

Baker, S. R., Bloom, N., Davis, S. J., \& Kost, K. (2019). Policy News and stock market volatility. Hoover Institution Economics Working Paper. 19105.

Bilson, C. M., Brailsford, T. J., \& Hooper, V. J. (2001). Selecting macroeconomic variables as explanatory factors of emerging stock market returns. Pacific-Basin Finance Journal, Vol. 9(4), 401-426.

Black, F., Jensen, M., \& Scholes, M. S. (1972). The capital asset pricing model: Some empirical findings. In: Jensen, M. (Ed.), Studies in the theory of capital markets (pp. 79-124). New York, NY: Praeger Publishers.

Campbell JY, Yogo M (2006) Efficient tests of stock return predictability. “J Financ Econ” Vol. 81(1), 27-60.

Demir, C. (2019), "Macroeconomic Determinants of Stock Market Fluctuations: The Case of BIST100", Journal of Economics, Vol. 7, 1-14.

Demirer, R., Guota, R., Lv, Z. \& Wong, W. K. (2019). Equity return dispersion and stock market volatility; Evidence from multivariate linear and nonlinear causality tests. Journal of Sustainability, Vol.11(351), 1-15.

Duncan, A. S. and Kabundi, A. (2013). Domestic and foreign sources of volatility spillover to South African asset classes. Economic Modelling, 31: 566-573. 
Duncan, A. S. and Kabundi, A. (2014), "Global Financial Crisis and Time Varying Volatility Comovement in world equity markets", South African Journal of Economics Vol. 82:4 December 2014.

El Khoury, R. M. (2015). Do macroeconomic factors matter for stock returns? Evidence from the European automotive industry. International Journal of Monetary Economics and Finance, Vol. 8(1), 71-84.

El Mehdi, Imen Khanchel \& Mghaieth, Asma, 2017. "Volatility spillover and hedging strategies between Islamic and conventional stocks in the presence of asymmetry and long memory," Research in International Business and Finance, Elsevier, vol. 39(PA), 595-611.

Emenike, K. O. \& Okwuchukwu, O. (2014). Stock market return volatility and macroeconomic variables in Nigeria. International Journal of Empirical Finance, Vol.2(2), Pp.75 - 82.

Fama EF (1970) Efficient capital markets: a review of theory and empirical work. "J Financ", Vol. 25(2), 383-417.

Fama EF, French KR (1988) Dividend yields and expected stock returns. "J Financ Econ”, Vol. 22(1), $3-25$.

Ferrando, A. (2018), "Macroeconomic Impact on Stock Market Returns and Volatility: Evidence from Sri Lanka", Business and Economics Journal" Fernando, Bus Eco J, Vol. 9:4, 2-15.

Golez B, Koudijs P (2018) Four centuries of return predictability. "J Financ Econ” Vol.127(2), 248-263.

Haider, Haider and Ahmed. (2017), "Systematic Risk Factors and Stock Return Volatility", Applied Studies in Agri Business and Commerce, Vol. 11, Issue, 1-2, 61-70.

Hamad, B, S., Peretti, D, C and Chafri, S. (2018). "The Impact of the Exchange Rate Volatilities on Stock Markets Dynamics: Evidence from Tunisia and Turkey", Insurance Sciences, LSAFEA2429, F-69007, Lyon, France, 1-32.

Hammoudeh, S., Mensi, W., Reboredoc, J.C., Nguyen, D.K., 2014. Dynamic dependence of the global Islamic equity index with global conventional equity market indices and risk factors. Pac. Basin Financ. J. 30, 189-206.

Hasan, A., \& Zaman, A. (2017). Volatility nexus between stock market and macro- economic variables in Bangladesh: An extended GARCH approach. Scientific Annals of Economics and Business, Vol.64(2), 233-243.

Hsing, Y., \& Hsieh, W.-Y. (2012). Impacts of macroeconomic variables on the stock market index in Poland: New evidence. Journal of Business Economics and Management, Vol. 13(2), 334-343.

Huang, C.-F. (2012). A hybrid stock selection model using genetic algorithms and support vector regression. Applied Soft Computing, Vol. 12(2), Pp. 807-818.

Jareno, F., \& Negrut, L. (2016). US stock market and macroeconomic factors. Journal of Applied Business Research, Vol.32(1), 325-340.

Khoon, C. H., \& Gupta, G. S. (2001). A test of arbitrage pricing theory evidence from Malaysia. The Asia Pacific Journal of Economics \& Business, Vol. 5(1), 76-96.

Kruger, J. J., \& Rhein, K. (2015). Macroeconomic development and the life cycle of the German automobile industry, 1886-1939. Darmstadt Discussion Papers in Economics, Vol. 224(1), 1-19.

Kyereboah-Coleman, A., \& Agyire-Tettey, F. (2008). Impact of macroeconomic indicators on stock market performance: The case of the Ghana stock exchange. Journal of Risk Finance, Vol. 9, 365-378.

Markowitz, H. (1959). Portfolio selection: Efficient diversification of investment. New York, NY: John Wiley \& Sons.

Liu R, Yang J, Ruan C (2019) Expected stock return and mixed frequency variance risk premium data. "J Ambient Intell Human Comput" Vol. 1, 1-12.

Mala, R., \& Reddy, M. (2007). Measuring stock market volatility in an emerging economy. International Research Journal of Finance and Economics, Vol.8(1), 126-133.

Nizar, Muhammad Afdi. (2012). "Dampak Fluktuasi Harga Minyak Dunia Terhadap Perekonomian Indonesia”, Buletin Ilmiah Litbang Perdagangan, Vol. 6 No. 2. Jakarta. Badan Kebijakan Fiscal, Kementerian Keuangan-RI. 
Onakoya, A. B. (2013). Stock market volatility and economic growth in Nigeria. International Review of Management and Business Research, Vol.2(1), 15 - 26.

Roubaud, D., \& Arouri, M. (2018). Oil prices, exchange rates and stock markets under uncertainty and regime-switching. Finance Research Letters, (July 2017), 0-1.

Ross, S. (1976). The arbitrage theory of capital asset pricing. Journal of Economic Theory, Vol. 13(3), 341-360.

Saiti, B. and Masih, M. (2016), "The co-movement of selective conventional and Islamic stock indices: is there any impact on shariah compliant equity investment in China?", International Journal of Economics and Financial Issues, Vol. 6 No. 4, 1895-1905.

Zain, M, M, Darus, F and Ramli, A. (2015), "Islamic Ethical Practices and the Marketplace: Evidence from Islamic Financial Institutions”, Procedia Economics and Finance, Vol. 28 (2015), 266 273. 